\title{
Aeolian nutrient fluxes following wildfire in sagebrush steppe: implications for soil carbon storage
}

\author{
N. J. Hasselquist ${ }^{1, *}$, M. J. Germino ${ }^{1, * *}$, J. B. Sankey ${ }^{2, * * *}$, L. J. Ingram ${ }^{1, * * *}$, and N. F. Glenn ${ }^{2}$ \\ ${ }^{1}$ Department of Biological Sciences, Idaho State University, 921 S 8th Ave, Stop 8007, Pocatello, ID 83209, USA \\ ${ }^{2}$ Department of Geosciences, Idaho State University-Boise, 322 E. Front St., Suite 240, Boise, ID 83702, USA \\ * current address: Department of Forest Ecology and Management, Swedish University of Agricultural Sciences (SLU), \\ Skogsmarksgrand 1, Umea, 90183, Sweden \\ ** current address: USGS Forest and Rangeland Ecosystem Science Center-Snake River Field Station, 970 Lusk St, Boise, \\ ID 83706, USA \\ *** current address: USGS Southwest Geographic Science Center and USA-National Phenology Network, 1955 E 6th St, \\ Tucson, AZ 85721, USA \\ ***** current address: Faculty of Agriculture, Food, and Natural Resources, The University of Sydney, 107 Cobbitty Rd, \\ Cobbitty, NSW 2570, Australia
}

Received: 17 June 2011 - Published in Biogeosciences Discuss.: 16 August 2011

Revised: 17 November 2011 - Accepted: 28 November 2011 - Published: 14 December 2011

\begin{abstract}
Pulses of aeolian transport following fire can profoundly affect the biogeochemical cycling of nutrients in semi-arid and arid ecosystems. Our objective was to determine horizontal nutrient fluxes occurring in the saltation zone during an episodic pulse of aeolian transport that occurred following a wildfire in a semi-arid sagebrush steppe ecosystem in southern Idaho, USA. We also examined how temporal trends in nutrient fluxes were affected by changes in particle sizes of eroded mass as well as nutrient concentrations associated with different particle size classes. In the burned area, total carbon $(\mathrm{C})$ and nitrogen $(\mathrm{N})$ fluxes were as high as $235 \mathrm{~g} \mathrm{C} \mathrm{m}^{-1} \mathrm{~d}^{-1}$ and $19 \mathrm{~g} \mathrm{~N} \mathrm{~m}^{-1} \mathrm{~d}^{-1}$ during the first few months following fire, whereas $\mathrm{C}$ and $\mathrm{N}$ fluxes were negligible in an adjacent unburned area throughout the study. Temporal variation in $\mathrm{C}$ and $\mathrm{N}$ fluxes following fire was largely attributable to the redistribution of saltation-sized particles. Total $\mathrm{N}$ and organic $\mathrm{C}$ concentrations in the soil surface were significantly lower in the burned relative to the unburned area one year after fire. Our results show how an episodic pulse of aeolian transport following fire can affect the spatial distribution of soil $\mathrm{C}$ and $\mathrm{N}$, which, in turn, can have important implications for soil $\mathrm{C}$ storage. These findings demonstrate how an ecological disturbance can exacerbate a geomorphic process and highlight the need for further research to better understand the role aeolian transport plays in the biogeochemical cycling of $\mathrm{C}$ and $\mathrm{N}$ in recently burned landscapes.
\end{abstract}

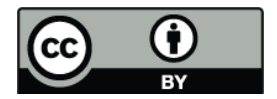

Correspondence to: N. J. Hasselquist (niles.hasselquist@slu.se)

\section{Introduction}

Wind erosion, the transport and redeposition of sediment by wind (i.e., aeolian transport) is an important phenomenon in arid and semi-arid landscapes (Goudie, 1983; Liu, 1985; Gillette and Hanson, 1989; Belnap et al., 2009) that has wide-ranging environmental, ecological and biogeomorphic implications (Chadwick et al., 1999; Reynolds et al., 2001; Okin et al., 2004; Whicker et al., 2004; Field et al., 2010; Harper et al., 2010). The transport and chemical composition of aeolian sediments can influence biophysical feedbacks that are important for plant community function in arid and semi-arid ecosystems (Schlesinger et al., 1996; Su et al., 2006; Ravi et al., 2007b, 2009; Okin et al., 2009). For example, previous studies have shown aeolian transport to strongly affect the spatial heterogeneity of soil resources ( $\mathrm{Su}$ et al., 2006; Ravi et al., 2007a; Li et al., 2008; Okin et al., 2009), which, in turn, can assist in developing "islands of fertility" (Schlesinger et al., 1996) or lead to the rapid loss of nutrients from the soil surface (Li et al., 2007).

One of the direct consequences of aeolian transport is the redistribution and potential loss of soil and associated soil nutrients on eroded surfaces (Trimble and Crossan, 2000; Reynolds et al., 2001; Okin et al., 2004; Li et al., 2007, 2008; Ravi et al., 2009). The mass of nutrients moved in aeolian sediments is a function of transport type (i.e., suspension, saltation or creep), amount and nutrient concentration of transported sediment. Wind-driven surface creep and saltating particles dominate at small scales (i.e., several meters) and are largely responsible for local redistribution

Published by Copernicus Publications on behalf of the European Geosciences Union. 


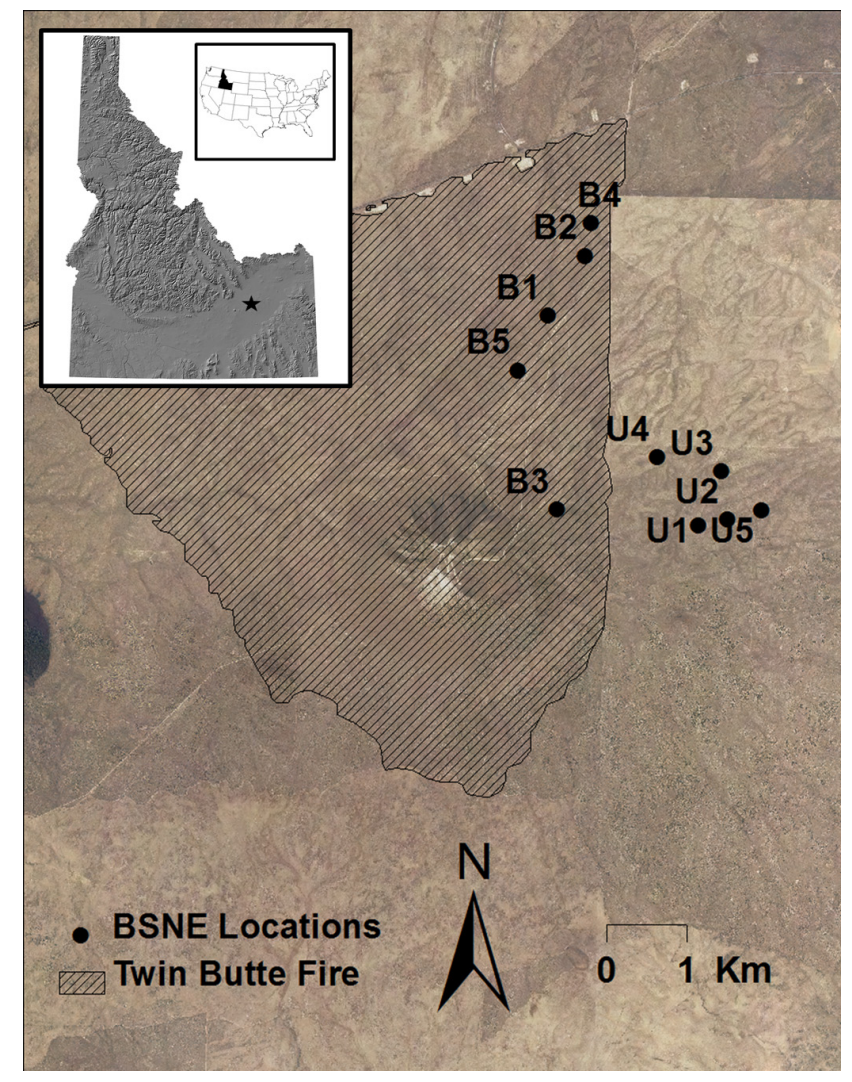

Fig. 1. (A) Location of study area relative to Idaho, with inset showing location of Idaho relative to USA. (B) Aerial photograph of the eastern Snake River plain (ESRP), Idaho, showing the area burned by the Twin Buttes wildfire in 2007 (hatched area), and the location of aeolian sediment collectors in the burned (B) and unburned (U) area.

of sediment within a landscape (Stout and Zobeck, 1996). Suspension-sized particles, on the other hand, can be transported over long distances (i.e., kilometers) and can be moved at regional and even global scales (Goudie and Middleton, 2006). Nutrient concentrations tend to vary among different sizes of sediment (Zobeck et al., 1989; Li et al., 2009) and particle size distribution of aeolian sediment varies with time in areas undergoing wind erosion (Zobeck et al., 1989; Gillette and Chen, 2001). The disturbance that triggers erosion can itself affect the biogeochemical composition of moved sediment, especially in the case of fire and the direct effects of combustion (Ravi et al., 2006, 2009; Rau et al., 2008). Thus, a mechanistic understanding of horizontal nutrient fluxes associated with aeolian transport on recently burned landscapes require an assessment of how particle size distribution, as well as nutrient concentration, of the eroded sediment varies in time after fire.

This study was part of a larger study examining aeolian sediment transport following wildfires in a semi-arid sagebrush steppe ecosystem on the eastern Snake River Plain
(ESRP), Idaho (Sankey et al., 2009a, b, 2010). During the first year following fire, Sankey et al. (2009a) reported a 28 to 67-fold increase in aeolian transport in a burned relative to an adjacent unburned area. Temporal and spatial variability in aeolian transport on the ESRP was largely attributable to climate and soil moisture until vegetation recovery in the first post-fire growing season (Sankey et al., 2009a, b) as well as differences in surface roughness (Sankey et al., 2010). Although Sankey et al. (2009a, b, 2010) examined the occurrence and causes of aeolian transport following fire on the ESRP, the direct consequences of aeolian transport on the redistribution of soil nutrients are still not well understood in this ecosystem.

The main objective of this study was to determine the horizontal fluxes of carbon $(\mathrm{C})$ and nitrogen $(\mathrm{N})$ occurring in the saltation zone (i.e., $1-2 \mathrm{~m}$ above the soil surface) as a result of aeolian transport following a wildfire in a semi-arid sagebrush steppe ecosystem. In a burned and an adjacent unburned area, we compared (1) the amount of aeolian transport, (2) the percent of $\mathrm{C}$ and $\mathrm{N}$ in the transported sediment, and (3) how relative changes in the particle size distribution and nutrient content of the aeolian sediment contributed to differences in the horizontal fluxes of $\mathrm{C}$ and $\mathrm{N}$. We hypothesized greater $\mathrm{C}$ and $\mathrm{N}$ fluxes would occur in the burned relative to the unburned area as a result of increased aeolian transport, despite the potential reduction in $\mathrm{C}$ and $\mathrm{N}$ concentrations in the soil surface caused by the wildfire. We also discuss the direct and indirect affects that increase horizontal nutrient fluxes have on soil C storage in recently burned sagebrush steppe.

\section{Methods and materials}

\subsection{Study site}

This study was conducted within a $16 \mathrm{~km}^{2}$ area (Lat. $43^{\circ} 30^{\prime} \mathrm{N}$, Lon. $112^{\circ} 38^{\prime} \mathrm{W}, 1650 \mathrm{~m}$ elevation) near the southern border of the Department of Energys' Idaho National Laboratory (INL) on the eastern Snake River Plain (ESRP; Fig. 1). The area has a mean precipitation of approximately $216 \mathrm{~mm}$ annually. Mean annual temperature ranges between $7^{\circ} \mathrm{C}-13^{\circ} \mathrm{C}$, based on climate data from $1950-2005$ (NOAA INL Weather Center, 2008). The area we sampled is relatively flat with prevailing winds from the southwest.

Vegetation in the study area is dominated by Wyoming big sagebrush (Artemisia tridentata ssp. wyomingensis Rydb., absent from burned area) and an approximately even mix of bunchgrasses including bluebunch wheatgrass (Agropyron spicatum Pursh.), sandberg bluegrass (Poa secunda J. Presl) and Indian rice grass (Oryza hymenoides [Roem \& Schult.] Ricker ex Piper) and forbs that include longleaf phlox (Phlox longifolia Nutt.), spiny phlox (Phlox hoodii Richardson), tapertip hawksbeard (Crepis accuminata Nutt.) and shaggy fleabane (Erigeron pumilus Nutt). Soils on the ESRP are 
predominately aeolian in origin and are classified as Aridisols, which developed in loess deposited 12 000-70 000 years ago (Busacca et al., 2004). Soil surface textures range from silt loam to sandy loam (Hoover, 2010).

\subsection{Experimental design and sediment sampling}

In July 2007, the Twin Buttes fire, a naturally caused wildfire, burned nearly 3800 ha of semi-arid sagebrush steppe on the INL. The Twin Buttes fire produced a severely burned landscape with no vegetation cover until the following spring. Maximum basal cover in the year following the fire was about $5 \%$ and was comprised mainly of grasses and forbs (Sankey et al., 2010). The burned and unburned sites were topographically and geomorphically similar (Sankey et al., 2009a), and therefore differences in aeolian transport between these two areas were largely attributable to the fire. We selected five locations in the burned area and five locations in an adjacent unburned area (Fig. 1). At each location, we installed a tower with five omnidirectional passive sediment collectors [Big Springs Number Eight $\left(\mathrm{BSNE}^{\circledR}\right)$, Custom Products, Big Springs, TX, USA] mounted at 0.05, $0.10,0.20,0.55$ and $1.00 \mathrm{~m}$ heights above ground immediately following containment of the fire. Collections were made approximately monthly from October 2007 to October 2008 in the burned area and less frequently (approximately once every two months) in the unburned area because of limited aeolian activity. Samples collected from the burned and unburned area during the same month in October 2007 (Fall 2007), April 2008 (Spring 2008), August 2008 (Summer 2008) and October 2008 (Fall 2008) were analyzed and presented here.

Sediment was collected at each height, placed in paper bags, dried at $105^{\circ} \mathrm{C}$ for $48 \mathrm{~h}$ and weighed to a precision of $0.1 \mathrm{mg}$. Sediment was then passed through a series of sieves to separate each sample into particle size classes of: $<106$, $106-500$ and $>500 \mu \mathrm{m}$. These size classes correspond to different aeolian transport processes, where particles $<106 \mu \mathrm{m}$ in diameter tend to be transported via the suspension process (Lyles, 1988) and particles $106-500 \mu \mathrm{m}$ in diameter are more likely transported via the saltation process (Fryrear et al., 1991), though we acknowledge these threshold sizes are approximate and can vary among studies and soil types. For this study we defined aeolian sediment as all material collected in BSNE collectors, which included both mineral particles as well as low-density particles of organic material.

\subsection{Sediment transport calculations}

The amount of sediment in each size class was determined for the five different heights $(0.05,0.10,0.20,0.55$ and $1.0 \mathrm{~m}$ ) in order to calculate rates of sediment transport (sediment flux and sediment discharge). Rates of sediment transport were calculated as described in Van Donk et al. (2003). Briefly, aeolian sediment flux $\left(\mathrm{kg} \mathrm{m}^{-2} \mathrm{~d}^{-1}\right)$ for each tower was first calculated for each sediment sampling interval and height as:

mass $\cdot$ area $^{-1} \cdot$ time $^{-1}$

where mass is $\mathrm{kg}$ of sediment, area is the size of the opening on the BSNEC sampler $\left(0.0002 \mathrm{~m}^{2}\right.$ at heights 0.05 and $0.10 \mathrm{~m}$, and $0.001 \mathrm{~m}^{2}$ at $0.20,0.55$ and $1.0 \mathrm{~m}$ ), and time is the sampling interval in days. Sediment flux was then plotted as a function of sample height for each tower and sampling interval. A power model was fitted to each plot and integrated over $2.0 \mathrm{~m}$ to calculate sediment discharge for each tower ( $n=5$ per site) and sampling interval with units of $\mathrm{kg} \mathrm{m}^{-1} \mathrm{~d}^{-1}$ (Van Donk et al., 2003):

$\int_{\text {height }=0}^{2 m}$ mass $\cdot$ area $^{-1} \cdot$ time $^{-1}$

We omitted sediment discharge estimates for which the $r^{2}$ value of the power model was less than 0.80 from further statistical analyses, so sample size in the burned and unburned area ranged between three and five height-integrated flux measurements for each time period. It is important to note that sediment discharge is calculated from the integration across a vertical profile, and therefore represents the horizontal flux of sediment with units of $\mathrm{kg} \mathrm{m}^{-1} \mathrm{~d}^{-1}$.

\subsection{Nutrient analyses}

For each sampling date and location, a subsample of aeolian sediment $(0.5 \mathrm{~g})$ from each particle size class was taken for total $\mathrm{C}$ and $\mathrm{N}$ analyses. Samples for nutrient analyses were ground with a Wig-L Bug grinding mill (International Crystal Lab, Garfield, New Jersey, USA) to a fine powder. Samples were analyzed for total $\mathrm{C}$ and $\mathrm{N}$ using an elemental analyzer (Model ESC 4010, Costech, Valencia, CA, USA). Horizontal fluxes of $\mathrm{C}$ and $\mathrm{N}$ were calculated by multiplying nutrient concentrations ( $\mathrm{g} \mathrm{C}$ or $\mathrm{N} \mathrm{kg}^{-1}$ sediment) by sediment discharge rates $\left(\mathrm{kg}\right.$ sediment $\mathrm{m}^{-1} \mathrm{~d}^{-1}$ ) for each size class and sampling date, which resulted in estimates of horizontal nutrient fluxes in units of $\mathrm{g} \mathrm{C}$ or $\mathrm{N} \mathrm{m}^{-1} \mathrm{~d}^{-1}$.

In early November 2008, soil samples were collected from the soil surface for total $\mathrm{C}$ and $\mathrm{N}$ analyses. Within both the burned and unburned area, 20 random soil samples were collected from the top $1 \mathrm{~cm}$ of the soil profile. Total $\mathrm{C}$ and $\mathrm{N}$ concentrations were determined as described above for aeolian sediment. Inorganic $\mathrm{C}$ was previously determined for a set of surface soils in both the burned and unburned area (Hoover, 2010). Using these estimates of inorganic C, organic $\mathrm{C}$ of surface soils was calculated as the difference between total $\mathrm{C}$ and inorganic $\mathrm{C}$. Inorganic $\mathrm{C}$ could not be determined in the aeolian sediment because the amount of sediment collected was often too small to perform both total C and inorganic $\mathrm{C}$ analyses. 

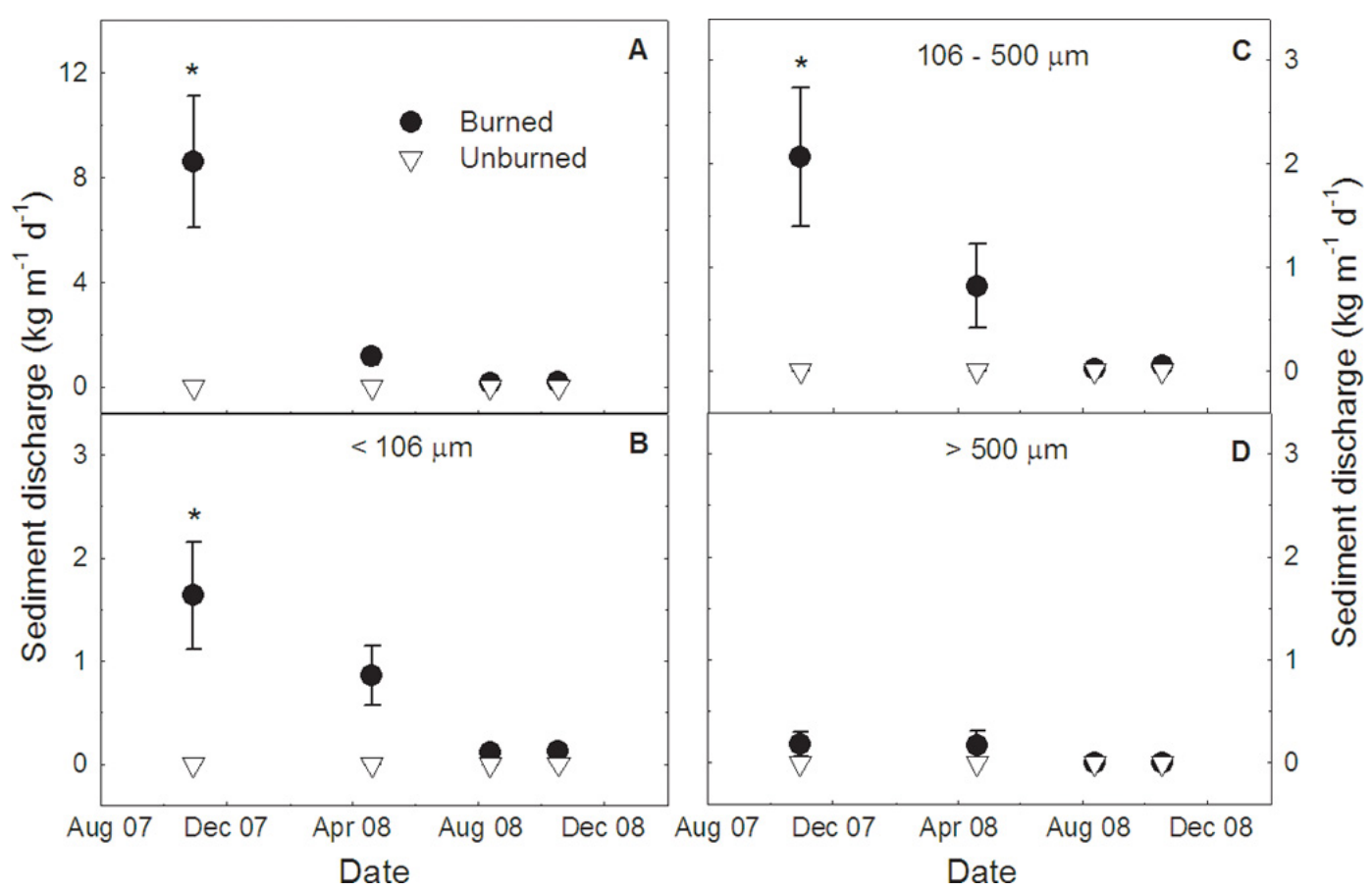

Fig. 2. Mean $( \pm \mathrm{SE})$ sediment discharge in the burned (filled circles) and unburned (open triangle) area during the first year following the Twin Buttes fire. Total sediment discharge (A), sediment discharge for the suspension $(<106 \mu \mathrm{m})$ size class $(\mathbf{B})$, saltation $(106-500 \mu \mathrm{m})$ size class $(\mathbf{C})$ and the largest size class of eroded sediment (D). Values for each sampling period consist of 3-5 height-integrated flux measurements $(*$ denotes significant site differences at $P<0.05$ ).

\subsection{Statistical analysis}

To evaluate the effect of fire on sediment discharge and horizontal nutrient fluxes in the year following the fire we used a two-way ANOVA with area (burned or unburned) and time (Fall 2007, Spring 2008, Summer 2008, and Fall 2008) as fixed factors. To detect differences among size classes, nutrient concentrations, and discharge of sediment we used a three-way ANOVA with area, time, and particle size class as fixed factors. We followed these analyses with post hoc tests using Bonferroni corrections to determine significant differences. Sediment discharge and nutrient data were transformed prior to being subjected to ANOVA (though values presented are mean $\pm \mathrm{SE}$ of non-transformed data). All statistical analyses were performed using SPSS statistical software (SPSS Inc., v 16.0, 2007).

\section{Results}

\subsection{Total sediment discharge}

Total sediment discharge was nearly three orders of magnitude greater in the burned relative to unburned area in Fall 2007, but did not differ thereafter as sediment discharge in the burned area significantly decreased to levels comparable to the unburned area (Fig. 2a). In the unburned area, sediment discharge was negligible and did not differ among sampling periods (Fig. 2a). Average sediment flux rates $\left(\mathrm{kg} \mathrm{m}^{-2} \mathrm{~d}^{-1}\right)$ at the different heights and total sediment discharge $\left(\mathrm{kg} \mathrm{m}^{-1} \mathrm{~d}^{-1}\right)$ for the burned and unburned area are shown for the different sampling periods in Appendix A.

Sediment discharge of the suspension- and saltation-sized particles was significantly greater in the burned relative to the unburned area in Fall 2007, but not thereafter as discharge in the burned area significantly decreased during the study (Fig. 2b, c). Sediment discharge of the largest size class did not differ between the burned and unburned area during the study (Fig. 2d). Average flux rates $\left(\mathrm{kg} \mathrm{m}^{-2} \mathrm{~d}^{-1}\right)$ at the different heights and total sediment discharge $\left(\mathrm{kg} \mathrm{m}^{-1} \mathrm{~d}^{-1}\right)$ for the different particle size classes in the burned and unburned area are shown for the different sampling periods in Appendix B and $\mathrm{C}$, respectively.

\subsection{Nutrient concentrations}

Overall, total C concentrations of aeolian sediment differed significantly among particle size classes, with the highest concentrations in the largest $(>500 \mu \mathrm{m})$ size class $(22.52 \pm$ $1.05 \%)$, intermediate concentrations in the saltation (106$500 \mu \mathrm{m})$ size class $(10.46 \pm 0.68 \%)$, and the lowest concentrations in the suspension $(<106 \mu \mathrm{m})$ size class $(2.30 \pm$ $0.17 \%$ ). There were no differences in $\mathrm{C}$ concentrations 
between the burned and unburned sites within any particle size class.

Total $\mathrm{N}$ concentrations of aeolian sediment essentially paralleled that of $\mathrm{C}$. $\mathrm{N}$ concentrations of aeolian sediment differed significantly among particle size classes, with the highest $\mathrm{N}$ concentrations in the largest size class $(1.50 \pm 0.11 \%)$, intermediate concentrations in the saltation size class $(0.79 \pm$ $0.06 \%$ ), and the lowest concentrations in the suspension size class $(0.18 \pm 0.01 \%)$. There were no differences in $\mathrm{N}$ concentrations between the burned and unburned area within any particle size classes.

At the end of our study period, total $\mathrm{N}$ and organic $\mathrm{C}$ concentrations in the soil surface $(1 \mathrm{~cm}$ depth) was significantly lower in the burned $(0.21 \pm 0.01 \%$ and $2.03 \pm 0.12 \%$; for total $\mathrm{N}$ and organic $\mathrm{C}$, respectively) relative to the unburned area $(0.26 \pm 0.02 \%$ and $2.75 \pm 0.31 \%)$.

\subsection{Horizontal nutrient fluxes}

In general, horizontal fluxes of $\mathrm{C}$ were nearly three orders of magnitude greater in the burned relative to the unburned area (79.62 $\pm 35.69 \mathrm{~g} \mathrm{C} \mathrm{m}^{-1} \mathrm{~d}^{-1}$ and $0.13 \pm 0.03 \mathrm{~g} \mathrm{C} \mathrm{m}^{-1} \mathrm{~d}^{-1}$, respectively). Horizontal $\mathrm{C}$ fluxes differed significantly between the burned and unburned area in Fall 2007, but not thereafter as horizontal $\mathrm{C}$ fluxes in the burned area significantly decreased to rates comparable to the unburned area (Fig. 3a). In contrast, horizontal $\mathrm{C}$ fluxes in the unburned area were negligible and did not differ among sampling periods. Overall, horizontal flux of $\mathrm{N}$ also differed between the burned and unburned area $\left(7.82 \pm 3.38 \mathrm{~g} \mathrm{~N} \mathrm{~m}^{-1} \mathrm{~d}^{-1}\right.$ and $0.01 \pm 0.00 \mathrm{~g} \mathrm{~N} \mathrm{~m}^{-1} \mathrm{~d}^{-1}$, respectively). As observed for horizontal $\mathrm{C}$ fluxes, significant differences in horizontal fluxes of $\mathrm{N}$ between the burned and unburned area were only detected in Fall 2007, but not thereafter as horizontal $\mathrm{N}$ fluxes in the burned area significantly decreased during the study (Fig. 3b). Horizontal $\mathrm{N}$ fluxes in the unburned area were negligible and did not differ among sampling periods.

\subsection{Horizontal nutrient fluxes among particle size classes}

In general, mean horizontal $\mathrm{C}$ flux for the saltation size class $\left(29.38 \pm 14.45 \mathrm{~g} \mathrm{C} \mathrm{m}^{-1} \mathrm{~d}^{-1}\right)$ was significantly greater than both the suspension and largest size classes $(4.54 \pm$ $1.78 \mathrm{~g} \mathrm{C} \mathrm{m}^{-1} \mathrm{~d}^{-1}$ and $7.89 \pm 4.79 \mathrm{~g} \mathrm{C} \mathrm{m}^{-1} \mathrm{~d}^{-1}$, respectively). Horizontal $\mathrm{C}$ fluxes in the saltation size class differed significantly between the burned and unburned area in Fall 2007, but not thereafter as horizontal $\mathrm{C}$ fluxes in the burned area significantly decreased to rates comparable to the unburned area (Fig. 4b). Horizontal $\mathrm{C}$ fluxes in the suspension and largest size classes did not differ between the burned and unburned area during the study (Fig. 4a, c).

Horizontal $\mathrm{N}$ fluxes essentially paralleled horizontal $\mathrm{C}$ fluxes. Mean horizontal $\mathrm{N}$ flux for the saltation size class $\left(2.40 \pm 1.19 \mathrm{~g} \mathrm{~N} \mathrm{~m}^{-1} \mathrm{~d}^{-1}\right)$ was significantly greater than

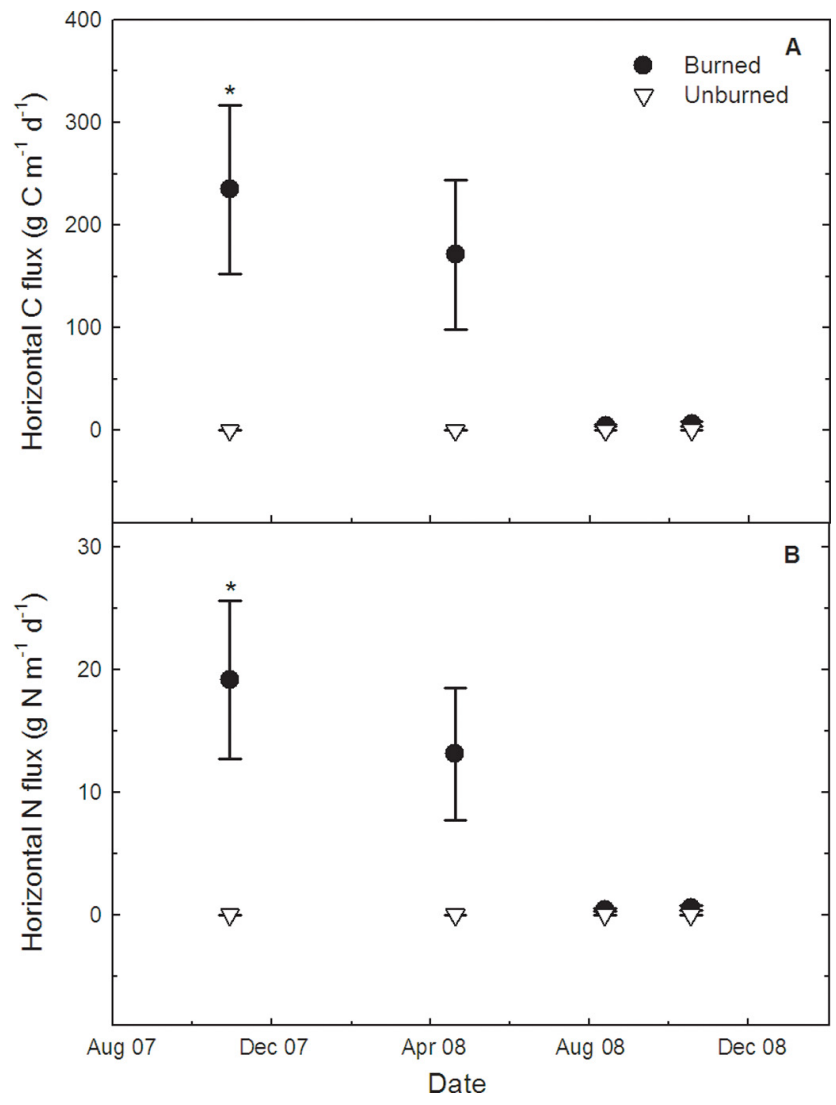

Fig. 3. Mean ( \pm SE) horizontal fluxes of carbon (A) and nitrogen (B) in the burned (filled circles) and unburned (open triangles) area. Horizontal fluxes of $\mathrm{C}$ and $\mathrm{N}$ were calculated by multiplying nutrient concentrations ( $\mathrm{g} \mathrm{C}$ or $\mathrm{N} \mathrm{kg}^{-1}$ sediment) by sediment discharge rates ( $\mathrm{kg}$ sediment $\mathrm{m}^{-1} \mathrm{~d}^{-1}$ ) for each size class and sampling date $(*$ denotes significant site differences at $P<0.05)$.

both the suspension and largest size classes $(0.44 \pm 0.17 \mathrm{~g}$ $\mathrm{N} \mathrm{m}^{-1} \mathrm{~d}^{-1}$ and $0.50 \pm 0.30 \mathrm{~g} \mathrm{~N} \mathrm{~m}^{-1} \mathrm{~d}^{-1}$, respectively). Horizontal $\mathrm{N}$ fluxes in the saltation size class differed significantly between the burned and unburned area in Fall 2007, but not thereafter as horizontal $\mathrm{N}$ fluxes in the burned area significantly decreased during the study (Fig. 4e). Horizontal $\mathrm{N}$ fluxes in the suspension and largest size classes did not differ between the burned and unburned area during the study (Fig. 4d, f).

\section{Discussion}

Previous studies have examined the effect of fire on aeolian transport (Zobeck et al., 1989; Wiggs et al., 1994; Whicker et al., 2002; Vermeire et al., 2005; Ravi et al., 2006, 2007b; Sankey et al., 2009a, b, 2010), yet the majority of these studies have focused on factors that contribute to increase rates of aeolian transport, such as changes in vegetation cover and surface roughness (Zobeck et al., 1989; Wiggs et al., 1994; 

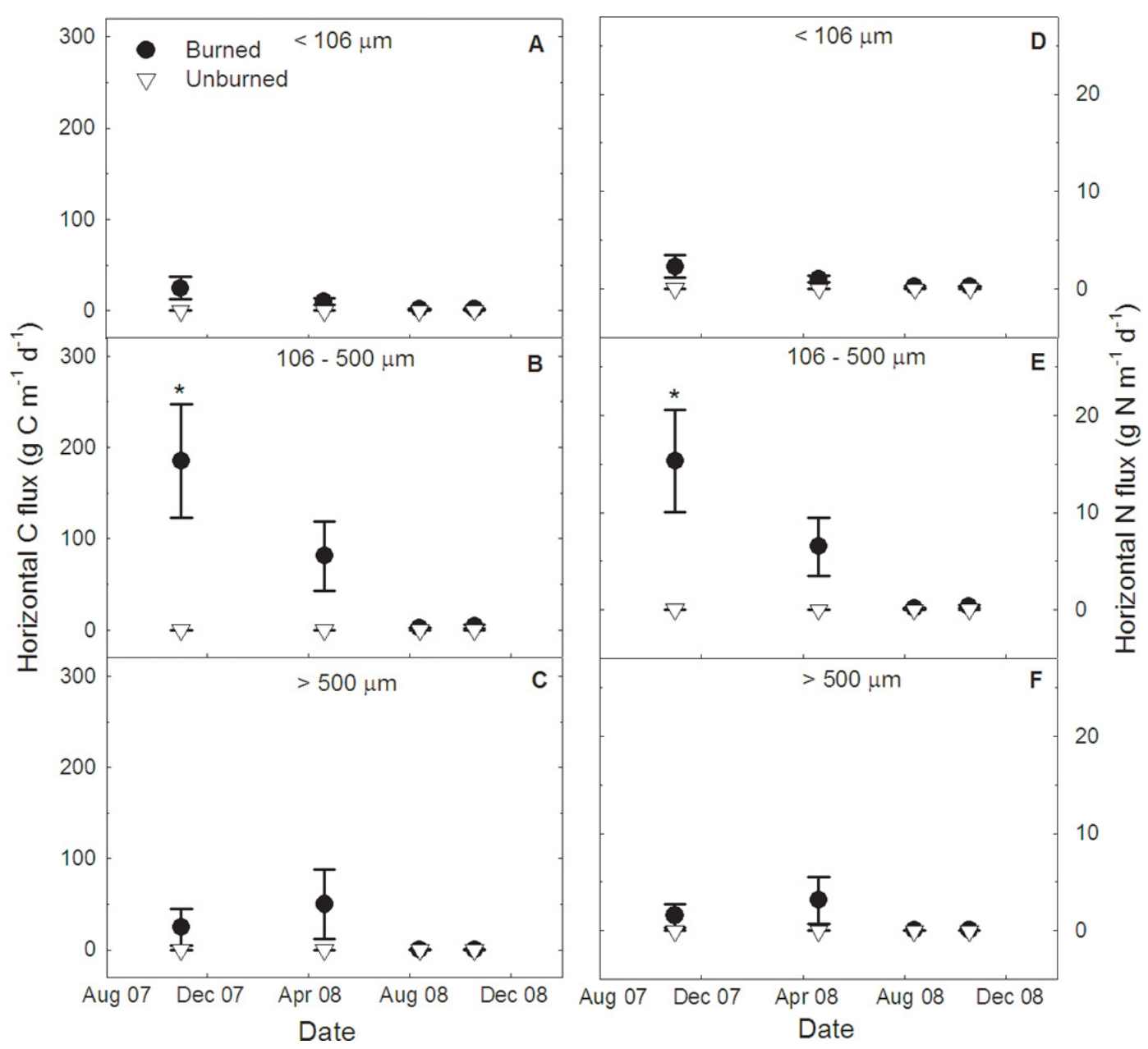

Fig. 4. Mean ( \pm SE) horizontal fluxes of carbon (A)-(C) and nitrogen (D)-(F) among the different particle size classes of sediment in the burned (filled circles) and unburned (open triangles) area (* denotes significant site differences at $P<0.05$ ).

Whicker et al., 2002; Sankey et al., 2009a, 2010) as well as changes in the physical and chemical properties of the soil surface (Ravi et al., 2009). Despite the recognized interactions among fire and aeolian transport on the redistribution of soil nutrients (see Ravi et al., 2009), our results are among the first to directly quantify post-fire, horizontal nutrient fluxes (i.e., via sediment captured from air) in a sagebrush steppe ecosystem. Nutrient fluxes associated with aeolian sediment in the saltation zone were as high as $235 \mathrm{~g} \mathrm{C}$ $\mathrm{m}^{-1} \mathrm{~d}^{-1}$ and $19 \mathrm{~g} \mathrm{~N} \mathrm{~m}^{-1} \mathrm{~d}^{-1}$ in the burned area during the first few months following fire, whereas $\mathrm{C}$ and $\mathrm{N}$ fluxes were negligible in an adjacent unburned area. Such a large pulse of nutrient-rich aeolian sediment can lead to the rapid loss of $\mathrm{C}$ and $\mathrm{N}$ from the soil surface, which, in turn, can have important implications for long-term soil C storage in recently burned sagebrush steppe.

It is important to note that differences in aeolian transport between the burned and unburned area were only detected in the first few months following the fire. This pulse of aeolian transport following the Twin Buttes fire was comparable to post-fire aeolian transport reported in Africa, Australia, and elsewhere in the USA (Wasson and Nanninga, 1986; Zobeck et al., 1989; Wiggs et al., 1994; Whicker et al., 2002; Vermeire et al., 2005), except that background aeolian transport was relatively lower in undisturbed ESRP and the post-fire pulse of aeolian transport was relatively intense and only occurred over a few months.

In addition to increased rates of aeolian transport, we observed significantly higher horizontal nutrient fluxes in the burned area during the first few months following the fire. Previous studies have shown that suspension-sized particles generally contain disproportionately greater amounts of nutrients, and consequently the loss of these particles due to aeolian transport may be an important mechanism leading to nutrient depletion in natural landscapes (Larney et al., 1998; Neff et al., 2005; Li et al., 2009; Harper et al., 2010). However, the majority of studies we are aware of have focused on landscapes with a long history of wind erosion. Unburned 
sagebrush steppe on the ESRP, on the other hand, has experienced little aeolian losses in recent history and is often characterized by the presence of fine-textured surface soils and the lack of contemporary (i.e., recent decades-centuries) geomorphic evidence of aeolian transport. The impacts of aeolian transport on soil texture and nutrient redistribution could therefore differ substantially at our site compared to landscapes with more frequent episodes of contemporary wind erosion. Interestingly, we observed higher $\mathrm{C}$ and $\mathrm{N}$ concentrations for the coarser, saltation-sized particles relative to the finer, suspension-sized particles. The higher $\mathrm{C}$ and $\mathrm{N}$ concentrations for saltation-sized particles at least partly reflects a greater proportion of organic matter in this size class $(19.7 \pm 1.3 \%$; determine through mass loss upon combustion) relative to suspension-sized particles $(4.0 \pm 0.2 \%)$ that consisted mostly of mineral particles with less organic matter (M. Germino, unpublished data). In addition, soil microaggregates $(53-250 \mu \mathrm{m})$ can contain higher concentrations of nutrients than clay and silt particles $(<53 \mu \mathrm{m}$; Wick et al., 2008), which could also help explain higher $\mathrm{C}$ and $\mathrm{N}$ concentrations for the saltation-sized particles.

Such a large pulse of nutrient-rich aeolian sediment following fire appeared to have dramatic effects on near surface soil nutrient pools in this ecosystem. For instance, total $\mathrm{N}$ concentrations from the top $1 \mathrm{~cm}$ of the soil profile were $19 \%$ lower in the burned relative to the unburned area $(0.21 \%$ and $0.26 \%$, respectively), whereas soil organic $\mathrm{C}$ concentrations was $26 \%$ higher in the unburned relative to the burned area ( $2.75 \%$ and $2.03 \%$, respectively). The losses reported here are comparable to what $\mathrm{Li}$ et al. (2007) found at the Jornada Experimental Range in southern New Mexico, where organic $\mathrm{C}$ and $\mathrm{N}$ decreased $25 \%$ in the top $5 \mathrm{~cm}$ of the soil due to aeolian fluxes. We acknowledge that lower total $\mathrm{N}$ and organic $\mathrm{C}$ concentrations in the soil surface in the burned area may have, in part, been the result of volatilization during combustion as suggested by slightly lower percent $\mathrm{C}$ and $\mathrm{N}$ in aeolian sediment immediately after the fire from the burned $(7.52 \pm 2.19 \%$ and $0.53 \pm 0.13 \%$; for $\mathrm{C}$ and $\mathrm{N}$ respectively) compared to the unburned area $(10.93 \pm 3.38 \%$ and $0.87 \pm 0.32 \%)$. However, given the large differences in horizontal nutrient fluxes between the burned and unburned area, it appears that aeolian transport plays an important role in the redistribution of soil nutrients in recently burned sagebrush steppe.

Horizontal nutrient fluxes, by themselves, do not directly quantify the amount of nutrients lost per unit ground area. We therefore performed a simple calculation to provide an estimate of the amount of $\mathrm{C}$ and $\mathrm{N}$ lost from the burned area as a result of aeolian transport. Using soil erosion bridges, Sankey et al. (2010) reported a mean rate of surface deflation of $2.1 \mathrm{~mm} \mathrm{y}^{-1}$ in the same burned site, which was equal to the loss of $2.63 \times 10^{4} \mathrm{~kg}$ soil ha $\mathrm{ha}^{-1} \mathrm{y}^{-1}$. Although there was some indication of local redistribution of sediment within the burned area, the burned area as a whole exhibited net deflation and thus soil loss. By multiplying the amount of sedi- ment loss by the average percent $\mathrm{C}$ and $\mathrm{N}$ of aeolian sediment from the burned area, we estimate that $1.51 \times 10^{3} \mathrm{~kg} \mathrm{C}^{-1}$ and $123 \mathrm{~kg} \mathrm{~N} \mathrm{ha}^{-1}$ might have been lost from the burned area during the first year following fire. For comparison, at a nearby site on the ESRP that had not burned recently, McGonigle et al. (2005) reported an annual increase in surface soil organic $\mathrm{C}$ of $0.5 \mathrm{~g} \mathrm{~kg}^{-1}$ through litter input, which corresponds to roughly $81 \mathrm{~kg} \mathrm{Cha}^{-1} \mathrm{y}^{-1}$. Thus, the large pulse of aeolian transport during the first year following fire appeared to have caused a rapid loss of soil $\mathrm{C}$, which is roughly equivalent to 19 years of soil $\mathrm{C}$ accumulation via litter input in this semi-arid ecosystem. This finding is consistent with other studies that have indentified aeolian transport as an important mechanism by which soil surface can become depleted in C (Delany and Zenchelsky, 1976; Harper et al., 2010).

In addition to the immediate loss of soil $\mathrm{C}$ as a result of increase aeolian transport, soil $\mathrm{C}$ may be further reduced in the burned area by a reduction in post-fire vegetation recovery. As mentioned above, we estimated a loss of $123 \mathrm{~kg} \mathrm{~N}$ $\mathrm{ha}^{-1}$ from the burned site during the first year following fire. Because soil nutrients are concentrated in the upper soil layers in this ecosystem (McGonigle et al., 2005), losses of $\mathrm{N}$ from the soil surface could drastically affect plant productivity and/or lead to changes in species diversity. In the burned area, maximum basal cover in the year following the fire was roughly $5 \%$ and was comprised mainly of grasses and forbs. In contrast, the unburned area had $18 \%$ basal cover and contained an even mix of shrub and herbaceous species (Sankey et al., 2010). This change in species composition and reduction in plant biomass following the fire could, in turn, further reduce soil $\mathrm{C}$ in the long-term through a reduction in litter input and root production. Lal (2003) showed how increased rates of aeolian transport can affect soil $\mathrm{C}$ storage through the depletion of soil fertility and subsequent decrease in crop production. More detailed studies are needed to better understand the feedbacks between horizontal nutrient fluxes, postfire vegetation recovery and soil $\mathrm{C}$ storage in recently burned landscapes.

Although water is a major contributor to soil erosion globally (Middleton and Thomas, 1997), we focused on wind erosion because erosion by wind is the dominant transport process in arid and semi-arid environments (Ravi et al., 2007b; Field et al., 2011). Furthermore, Wilcox et al. (2011) recently showed that runoff and water erosion in sagebrush steppe ecosystems require much steeper slopes than the relatively flat sites we evaluated, and rainfall intensity did not appear conducive to generate the type of runoff needed for water erosion (see Sankey et al., 2009b). We also acknowledge that aeolian transport and associated horizontal nutrient fluxes depend on several other factors, such as fire intensity and duration, post-fire soil moisture conditions as well as chemical and physical controls on post-fire erodibility (as discussed in Sankey et al., 2009b).

Nutrient losses due to aeolian transport are often attributable to the redistribution of suspension-sized particles 
Table A1. Mean $( \pm \mathrm{SE})$ sediment flux $\left(\mathrm{kg} \mathrm{m}^{-2} \mathrm{~d}^{-1}\right)$ from BSNE collectors located at different heights $(0.05,0.10,0.20,0.55$ and $1.0 \mathrm{~m})$ in the recently burned and adjacent unburned area. Mean sediment flux was plotted as a function of sample height for each sampling date, and a power model was fitted to each plot to calculate sediment discharge $\left(\mathrm{kg} \mathrm{m}^{-1} \mathrm{~d}^{-1}\right)$ as described in Van Donk et al. (2003).

\begin{tabular}{|c|c|c|c|c|}
\hline Height & Fall 2007 & Spring 2008 & Summer 2008 & Fall 2008 \\
\hline Burned & \multicolumn{4}{|c|}{ Sediment flux $\left(\mathrm{kg} \mathrm{m}^{-2} \mathrm{~d}^{-1}\right)$} \\
\hline $5 \mathrm{~cm}$ & $31.72 \pm 11.53$ & $4.81 \pm 1.00$ & $0.35 \pm 0.06$ & $0.50 \pm 0.13$ \\
\hline $10 \mathrm{~cm}$ & $14.35 \pm 2.06$ & $2.88 \pm 0.44$ & $0.19 \pm 0.03$ & $0.31 \pm 0.08$ \\
\hline $20 \mathrm{~cm}$ & $6.92 \pm 2.13$ & $1.45 \pm 0.06$ & $0.14 \pm 0.03$ & $0.19 \pm 0.04$ \\
\hline $55 \mathrm{~cm}$ & $2.40 \pm 0.52$ & $0.57 \pm 0.04$ & $0.08 \pm 0.02$ & $0.11 \pm 0.03$ \\
\hline $100 \mathrm{~cm}$ & $1.28 \pm 0.24$ & $0.34 \pm 0.02$ & $0.06 \pm 0.01$ & $0.09 \pm 0.02$ \\
\hline Sediment discharge $\left(\mathrm{kg} \mathrm{m}^{-1} \mathrm{~d}^{-1}\right)$ & $8.61 \pm 2.52$ & $1.14 \pm 0.33$ & $0.13 \pm 0.04$ & $0.18 \pm 0.06$ \\
\hline Unburned & \multicolumn{4}{|c|}{ Sediment flux $\left(\mathrm{kg} \mathrm{m}^{-2} \mathrm{~d}^{-1}\right)$} \\
\hline $5 \mathrm{~cm}$ & $7.01 \times 10^{-3} \pm 4.0 \times 10^{-3}$ & $2.73 \times 10^{-4} \pm 1.34 \times 10^{-4}$ & $3.92 \times 10^{-3} \pm 9.76 \times 10^{-4}$ & $1.89 \times 10^{-2} \pm 3.0 \times 10^{-3}$ \\
\hline $10 \mathrm{~cm}$ & $4.72 \times 10^{-3} \pm 2.44 \times 10^{-3}$ & $1.61 \times 10^{-4} \pm 8.5 \times 10-5$ & $2.72 \times 10^{-3} \pm 4.09 \times 10^{-4}$ & $8.47 \times 10^{-3} \pm 2.32 \times 10^{-3}$ \\
\hline $20 \mathrm{~cm}$ & $1.56 \times 10^{-3} \pm 8.4 \times 10^{-4}$ & $3.03 \times 10^{-5} \pm 1.2 \times 10^{-5}$ & $3.00 \times 10^{-4} \pm 5.6 \times 10^{-5}$ & $1.14 \times 10^{-3} \pm 8.4 \times 10^{-5}$ \\
\hline $55 \mathrm{~cm}$ & $3.26 \times 10^{-4} \pm 3.04 \times 10^{-4}$ & $1.73 \times 10^{-4} \pm 5.7 \times 10^{-5}$ & $1.18 \times 10^{-3} \pm 8.65 \times 10^{-4}$ & $3.83 \times 10^{-4} \pm 5.1 \times 10^{-5}$ \\
\hline $100 \mathrm{~cm}$ & $3.80 \times 10^{-4} \pm 2.98 \times 10^{-4}$ & $1.39 \times 10^{-4} \pm 3.7 \times 10^{-5}$ & $2.1 \times 10^{-4} \pm 5.2 \times 10^{-5}$ & $3.99 \times 10^{-4} \pm 1.57 \times 10^{-4}$ \\
\hline Sediment discharge $\left(\mathrm{kg} \mathrm{m}^{-1} \mathrm{~d}^{-1}\right)$ & $1.0 \times 10^{-2} \pm 8 \times 10^{-3}$ & $1.0 \times 10^{-3} \pm 1.0 \times 10^{-4}$ & $1.0 \times 10^{-3} \pm 4.0 \times 10^{-4}$ & $6 \times 10^{-3} \pm 1.0 \times 10^{-3}$ \\
\hline
\end{tabular}

Table B1. Mean $( \pm \mathrm{SE})$ sediment flux $\left(\mathrm{kg} \mathrm{m}^{-2} \mathrm{~d}^{-1}\right)$ and sediment discharge $\left(\mathrm{kg} \mathrm{m}^{-1} \mathrm{~d}^{-1}\right)$ for different size classes of sediment in the burned area.

\begin{tabular}{|c|c|c|c|c|}
\hline Height & Fall 2007 & Spring 2008 & Summer 2008 & Fall 2008 \\
\hline$<106 \mu \mathrm{m}$ & \multicolumn{4}{|c|}{ Sediment flux $\left(\mathrm{kg} \mathrm{m}^{-2} \mathrm{~d}^{-1}\right)$} \\
\hline $5 \mathrm{~cm}$ & $6.16 \pm 0.38$ & $2.50 \pm 0.25$ & $0.26 \pm 0.03$ & $0.34 \pm 0.08$ \\
\hline $10 \mathrm{~cm}$ & $4.68 \pm 0.45$ & $1.87 \pm 0.19$ & $0.16 \pm 0.02$ & $0.22 \pm 0.04$ \\
\hline $20 \mathrm{~cm}$ & $1.99 \pm 0.44$ & $0.92 \pm 0.02$ & $0.12 \pm 0.03$ & $0.13 \pm 0.02$ \\
\hline $55 \mathrm{~cm}$ & $1.16 \pm 0.19$ & $0.51 \pm 0.03$ & $0.08 \pm 0.02$ & $0.08 \pm 0.02$ \\
\hline $100 \mathrm{~cm}$ & $0.83 \pm 0.24$ & $0.31 \pm 0.01$ & $0.05 \pm 0.01$ & $0.08 \pm 0.02$ \\
\hline Sediment discharge $\left(\mathrm{kg} \mathrm{m}^{-1} \mathrm{~d}^{-1}\right)$ & $1.64 \pm 0.53$ & $0.86 \pm 0.29$ & $0.11 \pm 0.04$ & $0.13 \pm 0.04$ \\
\hline $106-500 \mu \mathrm{m}$ & \multicolumn{4}{|c|}{ Sediment flux $\left(\mathrm{kg} \mathrm{m}^{-2} \mathrm{~d}^{-1}\right)$} \\
\hline $5 \mathrm{~cm}$ & $10.46 \pm 2.52$ & $2.17 \pm 0.76$ & $0.08 \pm 0.02$ & $0.15 \pm 0.08$ \\
\hline $10 \mathrm{~cm}$ & $6.22 \pm 0.78$ & $0.98 \pm 0.24$ & $0.04 \pm 0.01$ & $0.09 \pm 0.05$ \\
\hline $20 \mathrm{~cm}$ & $1.55 \pm 0.17$ & $0.51 \pm 0.08$ & $0.02 \pm 0.01$ & $0.06 \pm 0.02$ \\
\hline $55 \mathrm{~cm}$ & $0.39 \pm 0.23$ & $0.09 \pm 0.01$ & $8 \times 10^{-3} \pm 2 \times 10^{-3}$ & $0.03 \pm 8 \times 10^{-3}$ \\
\hline $100 \mathrm{~cm}$ & $0.09 \pm 0.04$ & $0.02 \pm 0.01$ & $4 \times 10^{-3} \pm 1 \times 10^{-3}$ & $0.01 \pm 2 \times 10^{-3}$ \\
\hline Sediment discharge $\left(\mathrm{kg} \mathrm{m}^{-1} \mathrm{~d}^{-1}\right)$ & $2.06 \pm 0.67$ & $0.82 \pm 0.41$ & $0.02 \pm 0.01$ & $0.05 \pm 0.02$ \\
\hline$>500 \mu \mathrm{m}$ & \multicolumn{4}{|c|}{ Sediment flux $\left(\mathrm{kg} \mathrm{m}^{-2} \mathrm{~d}^{-1}\right)$} \\
\hline $5 \mathrm{~cm}$ & $0.97 \pm 0.54$ & $0.14 \pm 0.04$ & $7.4 \times 10^{-3} \pm 2.7 \times 10^{-3}$ & $8 \times 10^{-3} \pm 2.5 \times 10^{-3}$ \\
\hline $10 \mathrm{~cm}$ & $0.44 \pm 0.09$ & $0.03 \pm 0.02$ & $1.9 \times 10^{-3} \pm 7 \times 10^{-4}$ & $7 \times 10^{-3} \pm 3.7 \times 10^{-3}$ \\
\hline $20 \mathrm{~cm}$ & $0.18 \pm 0.12$ & $0.02 \pm 0.01$ & $1.2 \times 10^{-3} \pm 3 \times 10^{-4}$ & $1.2 \times 10^{-3} \pm 6 \times 10^{-4}$ \\
\hline $55 \mathrm{~cm}$ & $0.02 \pm 0.01$ & $9 \times 10^{-4} \pm 1 \times 10^{-4}$ & $3 \times 10^{-4} \pm 1 \times 10^{-4}$ & $1 \times 10^{-4} \pm 1 \times 10^{-4}$ \\
\hline $100 \mathrm{~cm}$ & $2.4 \times 10^{-3} \pm 1 \times 10^{-4}$ & $2 \times 10^{-4} \pm 1 \times 10^{-4}$ & $2 \times 10^{-4} \pm 1 \times 10^{-4}$ & $3 \times 10^{-4} \pm 2 \times 10^{-4}$ \\
\hline Sediment discharge $\left(\mathrm{kg} \mathrm{m}^{-1} \mathrm{~d}^{-1}\right)$ & $0.18 \pm 0.12$ & $0.17 \pm 0.13$ & $2.0 \times 10^{-3} \pm 4.0 \times 10^{-4}$ & $2.0 \times 10^{-3} \pm 4.0 \times 10^{-4}$ \\
\hline
\end{tabular}

(Larney et al., 1998; Neff et al., 2005; Li et al., 2009; Harper et al., 2010). Vertical fluxes of particles smaller than $10 \mu \mathrm{m}\left(\mathrm{PM}_{10}, \mathrm{~kg} \mathrm{~m}-2\right.$ of ground area) are typically four orders of magnitude less than the associated horizontal sediment fluxes based on ratios of vertical/horizontal fluxes of 0.0001 in Gillette et al. (1997) and 0.0002 for another fire and erosion study using the same BSNE sediment collec- tors on the ESRP (Wagenbrenner et al., 2011). Our study is unique in that it clearly shows how the redistribution of saltation-sized sediment can contribute appreciably to nutrient losses from a recently burned area. Although sediment discharge for suspension- and saltation-sized particles were similar in the burned area, saltation-sized particles contained significantly higher percent $\mathrm{C}$ and $\mathrm{N}$. Greater $\mathrm{C}$ and $\mathrm{N}$ in 
Table C1. Mean $( \pm \mathrm{SE})$ sediment flux $\left(\mathrm{kg} \mathrm{m}^{-2} \mathrm{~d}^{-1}\right)$ and sediment discharge $\left(\mathrm{kg} \mathrm{m}^{-1} \mathrm{~d}^{-1}\right)$ for different size classes of sediment in the unburned area.

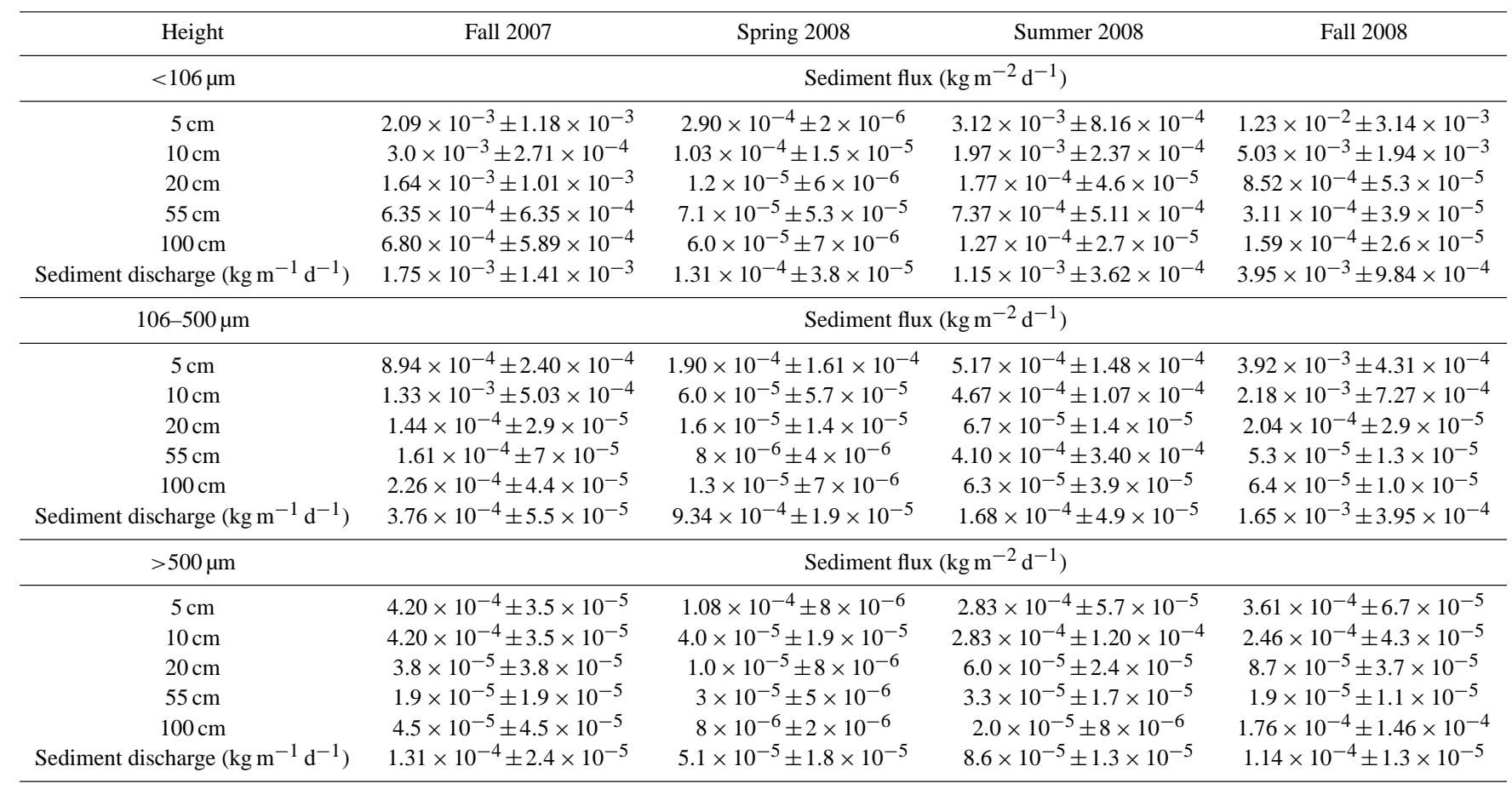

saltation-sized particles likely reflects the greater amount of organic matter observed in saltation-sized sediment relative to suspension-sized sediment. Organic matter is characterized by lower particle-density compared to mineral soil, and thus can be more buoyant and potentially capable of transport over longer distances. Additionally, because the burned area was nearly completely void of surface roughness elements during the first few months following the fire (Sankey et al., 2010), there was sufficient amount of time for iterative movement of particles via saltation off of the burned area. This notion of nutrient-rich saltation-sized particles being lost from the burned area is further supported by a reduction in the relative proportion of saltation-sized particles in residual soils in the burned (18\%) compared to the unburned $(12 \%)$ area one year after the fire (M. Germino, unpublished data). Understanding the relative importance of organic matter in aeolian transport processes may be crucial for sites that normally do not have much or any wind erosion, but then are suddenly subjected to aeolian processes following a disturbance, such as fire."

In conclusion, our results show how an ecological disturbance can exacerbate a geomorphic process, resulting in increased horizontal nutrient fluxes in a semi-arid sagebrush steppe ecosystem. In addition to causing a rapid loss of organic $\mathrm{C}$ in the soil surface, increased aeolian transport of nutrient-rich sediment could negatively affect post-fire vegetation recovery, thereby making recently burned areas more prone to further wind erosion as well as reducing soil $\mathrm{C}$ in the long-term through a reduction in litter input. Changes in climate along with an increase in invasive annual grasses have lead to an increase in fuel loads and fuel continuity on the ESRP. Consequently, the return intervals of wildfires has drastically shortened from a return interval of 32-70 years or longer before European colonization (Baker, 2006; Keane et al., 2008; Miller and Heyerdahl, 2008) to as short as five years in some places on the ESRP (Whisenant, 1990; Keane et al., 2008). Contemporary increases in fire frequency, therefore, might increase the frequency of post-fire erosion, as well as provide insufficient time for soil $\mathrm{C}$ and $\mathrm{N}$ stocks to recover between episodes of erosion. Thus, an overarching challenge for ecologists will be to better understand the feedbacks between horizontal nutrient fluxes following fire and post-fire vegetation recovery in order to predict how ecosystem functioning of sagebrush steppe will respond to future climate change scenarios.

Acknowledgements. This study was supported by grants to MJG, LJI and NFG from the Bureau of Land Management, NSF EPSCOR (\#EPS 0814387), and the US Army Research Office under grant number W911NF-07-1-0481. JBS was supported by a fellowship from the Inland Northwest Research Alliance. S.M. Stoller Corporation provided logistical and technical support at the Idaho National Laboratory. The authors specifically wish to acknowledge Roger Blew and Jeremy Shive of S.M. Stoller Corporation for their support of this project. Amber Hoover and Eli Eversole assisted with sediment sampling. Amber Hoover also provided additional soils nutrient data and Jeremy Greth assisted in soil analyses.

Edited by: M. Bahn 


\section{References}

Baker, W. L.: Fire and restoration of sagebrush ecosystems, Wildlife Society Bulletin, 34, 177-185, 2006.

Belnap, J., Reynolds, R. L., Reheis, M. C., Phillips, S. L., Urban, F. E., and Goldstein, H. L.: Sediment losses and gains across a gradient of livestock grazing and plant invasion in a cool, semiarid grassland, Colorado Plateau, USA, J. Aeolian Res., 1, 2743, 2009.

Busacca, A. J., Beget, J. E., Markewich, H. W., Muhs, D. R., Lancaster, N., and Sweeney, M. R.: Eolian sediments, in: The Quaternary Period in the United States, edited by: Gillespie, A. R., Porter, S. C., and Atwater, B. R., Elsevier, Amsterdam, 2004.

Chadwick, O. A., Derry, I. A., Vitousek, P. M., Huebert, B. J., and Hedin, L. O.: Changing sources of nutrients during four million years of ecosystem development, Nature, 397, 491-497, 1999.

Delany, A. C. and Zenchelsky, S.: The organic component of winderosion generated soil-derived aerosol, Soil Science, 121, 146155, 1976.

Field, J. P., Belnap, J., Breshears, D. D., Neff, J. C., Okin, G. S., Whicker, J. J., Painter, T. H., Ravi, S., Reheis, M. C., and Reynolds, R. L.: The ecology of dust, Front in Ecology and the Environment, 8, 423-430, 2010.

Field, J. P., Breshears, D. D., Whicker, J. J., and Zou, C. B.: Interactive effects of grazing and burning on wind- and water-driven sediment fluxes: rangeland management implications, Ecological Applications, 21, 22-32, 2011.

Fryrear, D. W., Stout, J. E., Hagen, L. J., and Vories, E. D.: Wind erosion: field measurements and analysis, Transactions of the ASAE, 34, 155-160, 1991.

Gillette, D. A. and Chen, W.: Particle production and aeolian transport from a "supply-limited" source area in the Chihuahuan desert, New Mexico, United States, J. Geophys. Res., 106, 52675278, 2001.

Gillette, D. A. and Hanson, K. J.: Spatial and temporal variability of dust production caused by wind erosion in the United States, J. Geophys. Res., 34, 2197-2206, 1989.

Gillette, D. A., Fryrear, D. W., Gill, T. E., Ley, T., Cahill, T. A., and Gearhart, E. A.: Relation of vertical flux of particles smaller than $10 \mu \mathrm{m}$ to total aeolian horizontal mass flux at Owens Lake, J. Geophys. Res.-Atmos., 102, 26009-26015, 1997.

Goudie, A. S.: Dust storms in space and time, Progress in Physical Geography, 7, 502-530, 1983.

Goudie, A. S. and Middleton, N. J.: Desert dust in the global system, Springer-Verlag, Germany, 2006.

Harper, R. J., Gilkes, R. J., Hill, M. J., and Carter, D. J.: Wind erosion and soil carbon dynamics in south-western Australia, Aeolian Research, 1, 129-141, 2010.

Hoover, A.: Relationships between soil heterogeneity and vegetation recovery in sagebrush steppe following wildfire and wind erosion, Ms Thesis, Idaho State University, USA, 2010.

Keane, R. E., Holsinger, L. M., Parsons, R. A., and Gray, K.: Climate changes effects on historical range and variability of two landscapes in western Montana, USA, Forest Ecology and Management, 254, 375-389, 2008.

Lal, R.: Soil erosion and the global carbon budget, Environment International, 29, 437-450, 2003.

Larney, F. J., Bullock, M. S., Janzen, H. H., Ellert, B. H., and Olson, E. S.: Wind erosion effects on nutrient redistribution and soil productivity, J. Soil Water Conserv., 53, 133-140, 1998.
Li, J., Okin, G. S., Alvarez, L., and Epstein, H.: Quantitative effects of vegetation cover on wind erosion and soil nutrient loss in a desert grassland of southern New Mexico, USA, Biogeochemistry, 85, 317-332, 2007.

Li, J., Okin, G. S., Alvarez, L., and Epstein, H.: Effects of wind erosion on the spatial heterogeneity of soil nutrients in two desert grassland communities, Biogeochemistry, 88, 73-88, 2008.

Li, J., Okin, G. S., and Epstein, H. E.: Effects of enhanced wind erosion on surface soil texture and characteristics of windblown sediment, J. Geophys. Res., 114, G02003, doi:10.1029/2008JG000903, 2009.

Liu, T. S.: Loess and the Environment, China Ocean Press, Beijing, 1985.

Lyles, L.: Basic wind erosion processes, Agriculture, Ecosystems and Environment, 22, 91-101, 1988.

McGonigle, T. P., Chambers, M. L., and White, G. J.: Enrichment over time of organic carbon and phosphorus in semiarid soil, Soil Sci. Soc. Am. J., 69, 1617-1626, 2005.

Middleton, N. and Thomas, D.: World atlas of desertification, Arnold, London, 1997.

Miller, R. F. and Heyerdahl, E. K.: Fine-scale variation of historical fire regimes in sagebrush-steppe and juniper woodlands: an example from California, USA, International Journal of Wildland Fire, 17, 245-254, 2008.

Neff, J. C., Reynolds, R. L., Belnap, J., and Lamothe, P.: Multidecadal impacts of grazing on soil physical and biogeochemical properties in southeast Utah, Ecological Applications, 15, 87-95, 2005.

NOAA INL Weather Center: http://niwc.noaa.inel.gov/climate.htm, accessed 22 September 2009, 2008.

Okin, G. S., Mahowald, N., Chadwick, O. A., and Artaxo, P.: Impact of desert dust on the biogeochemistry of phosphorus in terrestrial ecosystems, Global Biogeochemical Cycles, 18, GB2005, doi:10.1029/2003GB002145, 2004.

Okin, G. S., Parsons, A. J., Wainwright, J., Herrick, J. E., Bestelmeyer, B. T., Peters, D. C., and Fredrickson, E. L.: Do changes in connectivity explain desertification?, Bioscience, 59, 237-244, 2009.

Rau, B. M., Chambers, J. C., Blank, R. R., and Johnson, D. W.: Prescribed fire, soil, and plants: Burn effects and interactions in the central Great Basin, Rangeland Ecology and Management, 61, 169-181, 2008.

Ravi, S., D’Odorico, P., Herbert, B., Zobeck, T., and Over, T.: Enhancement of wind erosion by fire- induced water repellency, Water Resour. Res., 42, W11422, doi:10.1029/2006WR004895, 2006.

Ravi, S., D’Odorico, P., and Okin, G. S.: Hydrologic and aeolian controls on vegetation patterns in arid landscapes, Geophys. Res. Lett., 34, L24S23, doi:10.1029/2007GL031023, 2007 a.

Ravi, S., D’Odorico, P., Zobeck, T. M., Over, T. M., and Collins, S. L.: Feedbacks between fires and wind erosion in heterogeneous arid lands, J. Geophys. Res., 112, G04007, doi:10.1029/2007JG000474, 2007b.

Ravi, S., D’Odorico, P., Wang, L., White, C. S., Okin, G. S., Macko, S. A., and Collins, S. L.: Post-fire resource redistribution in desert grasslands: A possible negative feedback on land degradation, Ecosystems, 12, 434-444, 2009.

Reynolds, J. F., Belnap, J., Reheis, M., Lamothe, P., and Luiszer, F.: Eolian dust in Colorado Plateau soils: nutrient inputs and recent 
change in source, Proc. Natl. Acad. Sci., 98, 7123-7127, 2001.

Sankey, J. B., Germino, M. J., and Glenn, N. F.: Aeolian sediment transport following wildfire in a sagebrush steppe, J. Arid Environ., 73, 912-919, 2009a.

Sankey, J. B., Germino, M. J., and Glenn, N. F.: Relationships between post-fire aeolian transport to soil and atmospheric conditions, Aeolian Research, 1, 75-85, 2009b.

Sankey, J. B., Glenn, N. F., Germino, M. J., Gironella, A. I. N., and Thackray, G. D.: Relationships of aeolian erosion and deposition with LiDAR-derived landscape surface roughness following wildfire, Geomorphology, 119, 135-145, 2010.

Schlesinger, W. H., Raikes, J. A., Hartley, A. E., and Cross, A. F.: On the spatial pattern of soil nutrients in desert ecosystems, Ecology, 77, 364-374, 1996.

Stout, J. E. and Zobeck, T. M.: The Wolfforth field experiment: a wind erosion study, Soil Science, 161, 616-632, 1996.

Su, Y. Z., Li, Y. L., and Zhao, H. L.: Soil properties and their spatial pattern in a degraded sandy grassland under post-grazing restoration, Inner Mongolia, northern China, Biogeochemistry, 79, 297314, 2006.

Trimble, S. W. and Crossan, P.: U.S. soil erosion rates: myth and reality, Science, 289, 248-250, 2000.

Van Donk, S. J., Huang, X., Skidmore, E. L., Anderson, A. B., Gebhart, D. L., Prehoda, V. E., and Kellog, E. M.: Wind erosion from military training lands in the Mojave Desert, California, U.S.A, J. Arid Environ., 54, 687-703, 2003.

Vermeire, L. T., Wester, D. B., Mitchell, R. B., and Fuhlendorf, S. D.: Fire and grazing effects on wind erosion, soil water content, and soil temperature, J. Environmental Quality, 34, 1559-1565, 2005.

Wagenbrenner, N. S., Germino, M. J., Lamb, B. K., Foltz, R. B., and Robichaud, P. R.: Wind-erosion of soils burned by wildfire, in: Proceedings at the Internatinal Symposium Erosion and Landscape Evolution, 18-21 September, 711P0311cd.9, 2011.
Wasson, R. J. and Nanninga, P. M.: Estimating wind transport of sand on vegetated surfaces, Earth Surface Processes and Landforms, 11, 505-514, 1986.

Whicker, J. J., Breshears, D. D., Wasiolek, P. T., Kirchner, T. B., Tavani, R. A., Schoep, D. A., and Rodgers, J. C.: Temporal and spatial variation of episodic wind erosion in unburned and burned semi-arid shrubland, J. Environ. Quality, 31, 599-612, 2002.

Whicker, F. W., Hinton, T. G., MacDonell, M. M., Pinder, J. E., and Habegger, L. J.: Avoiding destructive remediation at DOE sites, Science, 303, 1615-1616, 2004.

Whisenant, S. G.: Changing fire frequency on Idaho's Snake River Plains: ecological and management implications, in: Proceedings - symposium on cheatgrass invasion, shrub die-off, and other aspects of shrub biology and management, edited by: McArthur, E. D., Romney, E. M., Smith, S. D. Tueller, and P. T., US Department of Agriculture Forest Service, 1990.

Wick, A. F., Stahl, P. D., and Ingram, L. J.: Aggregate-associated carbon and nitrogen in reclaimed sandy loam soils, Soil Sci. Soc. Am. J., 73, 1852-1860, 2008.

Wiggs, G. F., Livingstone, I., Thomas, D. S. G., and Bullard, J. E.: Effect of vegetation removal on airflow patterns and dynamics in the southwest Kalahari desert, Land Degradation and Rehabilitation, 5, 13-24, 1994.

Wilcox, B. P., Turnbull, L., Young, M. H., Williams, C. J., Ravi, S., Seyfried, M. S., Bowling, D. R., Scott, R. L., Germino, M. J., Caldwell, T. G. and Wainwright, J.:, 2011 Invasion of shrublands by exotic grasses: ecohydrological consequences in cold versus warm deserts, Ecohydrology, published online, doi:10.1002/eco.247, 2011.

Zobeck, T. M., Fryrear, D. W., and Pettit, R. D.: Management effects on wind-eroded sediment and plant nutrients, J. Soil Water Conserv., 44, 160-163, 1989. 